\title{
Research of Operation Modes of Heat Storage Tank in CHP Plant Using Numerical Simulation
}

\author{
Giedre Streckiene ${ }^{1}$, Violeta Miseviciute ${ }^{2},{ }^{1-2}$ Department of Building Energetics, Vilnius Gediminas Technical \\ University
}

\begin{abstract}
The installation of a heat storage tank is a very costeffective way to improve the performance and flexibility of a CHP plant. Such a heat storage tank usually accumulates heat by thermal stratification. This phenomenon is caused by the thermal buoyancy because of the difference in temperature between cold and hot water. The heat storage tank may have three operating modes, $i$. e. charge, discharge and storage in a CHP plant. When CHP units, which charge the heat storage tank, operate at full load, usually only two operation modes occur in the tank, i.e. charge and discharge.

The paper presents numerical simulation of heat storage tank operation modes in a CHP plant using PHOENICS - a multipurpose computation fluid dynamics (CFD) software. Twodimensional and three-dimensional transient models were created and solved numerically. Three domain grids were tested. Several charging and discharging processes with different flow rates were simulated. The influence of flow rate on the degree of thermal stratification during charging and discharging processes is analyzed. The computation possibilities and limitations of the numerical experiments are pointed out. Special attention is given to the validation of the numerical solutions. The validation of simulated results is made by comparison with the real data from the heat storage installed in the Hvide Sande CHP plant.
\end{abstract}

Keywords - CHP, heat storage tank, numerical simulation, thermal stratification

\section{INTRODUCTION}

Cogeneration (CHP), or the simultaneous production of electricity and heat, is being promoted at the EU level as a way of reducing greenhouse gas emissions from traditional power plants. CHP units are mostly considered as standalone facilities, although in reality they will be part of a system that also contains a back-up boiler and a heat storage tank [1]. A heat storage tank is one of the ways to partially decouple heat supply from electricity production. Without heat storage, the CHP operation is driven directly by heat demand; while the market prices paid for produced or consumed electricity vary significantly depending on the time of day [2, 3]. The combination of heat storage and CHP technologies assists in the achievement of goals for improving energy production efficiency and reducing environmental pollution.

The efficiency of heat storage is improved, when the water in the storage tank is stratified [4, 5]. Stratification of the water is caused by the difference in density between hot and cold water in tanks. Cold water remains at the bottom of the storage tank, while hot water flows to the top. The intermediate region is called the thermocline. The formation of the thermocline is determined by the geometry of the storage tank, the inlet, the hydrodynamics and thermal characteristics of the water flow in the tank.

The research on thermal stratification within the storage tank has been studied since the 1970s [6, 7]. At first, only one-dimensional models were developed and only after the 1990s, more investigations on two or more dimensional models were made [8].

A number of works about the thermal stratification in the heat storages of solar systems were examined. Most of them analyzed the operation of heat storage tanks under experimental conditions [7-11]. However, most of the systems operate under actual conditions. It can be noted that there are no detailed studies on heat storages installed in CHP plants. In the present work, numerical experiments were carried out on the actual heat storage tank that was installed in a CHP plant. The fulfilment of heat storage was influenced by the operation of heat generators which worked in the spot market. A numerical model was created using the CFD software PHOENICS. The results of the numerical thermal stratification simulation are presented and verified.

\section{HEAT STORAGE TANK IN THE CHP PLANT}

This section describes information about the actual operation of the heat storage tank installed in the CHP plant. The analyzed tank is part of the Hvide Sande (in Denmark) CHP system. The main generators in the Hvide Sande CHP plant are two identical gas fired engines of $3.77 \mathrm{MW}_{\mathrm{e}}$ and two boilers of $10 \mathrm{MW}_{\text {th }}$ and $4 \mathrm{MW}_{\text {th }}$. The heat storage tank has a volume of $2000 \mathrm{~m}^{3}$, equal to a heat capacity of 130 MWh [12]. The storage is characterized by the following features:

- Construction: above ground level tank with thermal insulation of $300 \mathrm{~mm}$;

- Storage medium: water;

- Charging/discharging: direct water exchange;

- Maximum flow rate: $200 \mathrm{~m}^{3} / \mathrm{h}$.

During the charging process, hot water at a temperature of $\sim 94-96{ }^{\circ} \mathrm{C}$ is supplied to the top of the storage tank, while the same amount of colder water $\left(\sim 44-46^{\circ} \mathrm{C}\right)$ is taken off from the storage bottom. The charging process starts, when the heat production is higher than the heat demand. During the discharge, the opposite process takes place.

The heat storage tank is usually filled with heat generated by gas engines in hours, where the electricity spot price is high, and it is rarely filled by boilers. This happens when some repairs are made for the gas engines [13]. A schematic diagram of the actual storage tank is presented in Fig. 1. 


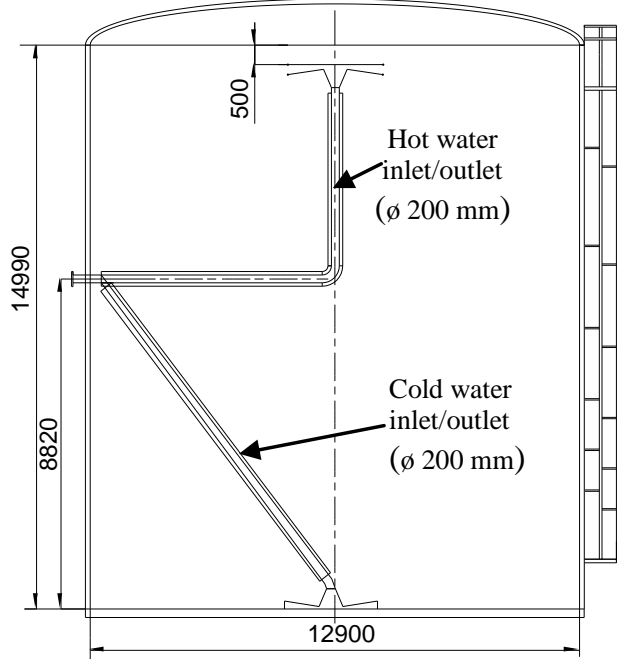

Fig. 1. Storage tank of the Hvide Sande CHP plant.

Actually, 16 temperature sensors (PT100) are installed inside the heat storage, but there is a possibility to get data only from 15 temperature sensors. The first meter is installed $0.5 \mathrm{~m}$ above the bottom and the last sensor is $0.5 \mathrm{~m}$ below the top diffuser. The used temperature sensors have tolerance class B. Error of the used temperature sensors ranges from $\pm 0.50{ }^{\circ} \mathrm{C}$ to $\pm 0.78{ }^{\circ} \mathrm{C}$ when the temperature of stored water is in the range of $40{ }^{\circ} \mathrm{C}$ to $95^{\circ} \mathrm{C}$. Data were collected with SCADA system and registered every 15 minutes during the training in EMD International A/S according to the Lifelong Learning Programme. The data were imported to Excel sheets. Operation of the heat storage tank during one week is shown in Fig. 2. We can see the charging and discharging processes in the upper part of the Figure.
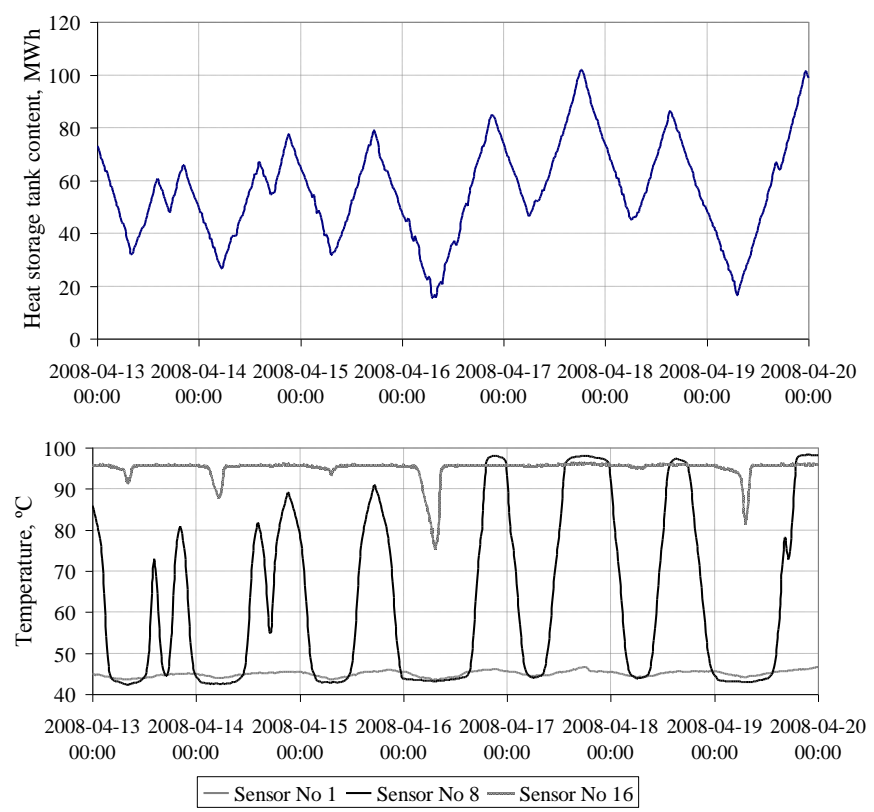

Fig. 2. Operation of the heat storage tank during one week: heat storage content (above) and variation of temperature inside the storage tank (below).
The Hvide Sande heat storage tank was usually charged once or twice a day. The main discharging process occurred at night when the electricity price is cheaper. At that time, the gas engines do not operate and consumers' heat demand is covered by the storage tank. The bottom part of Fig. 2 presents the temperature variation inside the heat storage tank. The change of temperature is small at the lowest and highest sensors (sensor No. 1 and sensor No. 16). The sensor No. 8 is at a height of $6.8 \mathrm{~m}$ and it falls into the intermediate zone, where the temperature varies the most.

\section{MATHEMATICAL AND NUMERICAL MODELS}

This section describes the basic formulation and numerical approach used to solve the phenomena taking place inside the heat storage tank.

The equations for temperature distribution simulation normally can be expressed in a vector form as [14]:

Continuity equation:

$$
\frac{\partial \rho}{\partial \tau}+(\rho \vec{v})=0
$$

Momentum equation:

$$
\rho \frac{\partial \vec{v}}{\partial \tau}+(\rho \vec{v} \cdot \nabla) \vec{v}=-\nabla p+\mu \nabla^{2} \vec{v}+\rho \vec{g},
$$

Energy equation:

$$
\frac{\partial T}{\partial \tau}+\vec{v} \cdot \nabla T=\frac{\lambda}{\rho c_{p}} \nabla^{2} T,
$$

where: $\rho$ - density, $g$ - gravitational constant, $p$ - pressure, $\tau$ - time, $\lambda$-thermal conductivity, $\vec{v}$ - velocity vector.

In this study, the numerical simulation of temperature stratification in the heat storage tank is performed using PHOENICS 3.5.1, where the own code is created as Q1 file. Q1, the user-readable input-data file, which is written in PIL, the PHOENICS Input Language, and is the main expression of what the user wishes to achieve. PHOENICS performs three main functions [15]:

- Problem definition (i.e. pre-processing), in which the user prescribes the situation to be simulated and the questions to be answered;

- Simulation (i.e. data-processing), by means of computation, of what the laws of science imply in the prescribed circumstances;

- Presentation (i.e. post-processing) of the results of the computation, by way of graphical displays, tables of numbers, and other means.

PHOENICS therefore, like many but not all CFD codes, has a distinct software module, or set of modules, for each of the above three functions. This software package provides a solution to the discretized version of sets of differential equations having the general form [15]: 


$$
\underbrace{\frac{\partial}{\partial \tau}\left(r_{i} \rho_{i} \Phi_{i}\right)}_{\text {transient }}+\operatorname{div}(\underbrace{r_{i} \rho_{i} \overrightarrow{\mathrm{v}}_{i} \Phi_{i}}_{\text {convection }}-\underbrace{r_{i} \Gamma_{\Phi i} \operatorname{grad} \Phi_{i}}_{\text {diffusion }})=\underbrace{r_{i}^{S_{\Phi i}}}_{\text {source }}
$$

where: $\tau$ - time; $r_{i}$ - volume fraction of phase $i ; \rho_{i}$ - density of phase $i ; \Phi_{i}$ - any conserved property of phase $i$, such as momentum per unit mass, turbulence energy, etc.; $\overrightarrow{\mathrm{v}}_{i}-$ velocity vector of phase $i ; \Gamma_{\Phi i}$ - the exchange coefficient of the entity $\Phi$ in phase $i ; \mathrm{S}_{\Phi i}$ - the source rate of $\Phi_{i}$.

When a single-phase phenomenon is in question, the volume fraction $r_{i}$ disappears from the equation above, which thus becomes:

$$
\frac{\partial}{\partial \tau}(\rho \Phi)+\operatorname{div}\left(\rho \overrightarrow{\mathrm{v}} \Phi-\Gamma_{\Phi} \operatorname{grad} \Phi_{i}\right)=S_{\Phi}
$$

In this analysis, $\Phi_{i}$ takes the following values, each of which gives rise to a particular conservation equation:

- $\Phi=1$ gives the continuity equation;

- $\Phi=v$ gives the radial direction momentum equation;

- $\Phi=w$ gives the axial direction momentum equation and

- $\Phi=c_{p} T$ gives the energy equation.

To simplify the problem, the following main assumptions were made:

- Axisymmetry, which reduces the problem from $3 \mathrm{D}$ to 2D;

- Incompressible and laminar flow;

- Walls of heat storage tank are very thin and they are not modelled, only thermal insulation is taken into account;

- Non-participating radiating medium.

All equations in PHOENICS are solved iteratively. To evaluate the convective and diffusive fluxes at the interfaces, the HYBRID scheme is used. In transient calculations, the velocity and temperature of the inflow are specified from the first calculation time step. The cylindrical polar coordinates are used.

The selected computational domain accounts for only half of the vertical section of the heat storage tank through axis $z$. Three sizes of domain grids in 2D coordinates were analyzed:

- $17 \times 43=799$ cells;

- $40 \times 58=2320$ cells and

- $104 \times 104=10816$ cells.

The geometrical model of the calculation domain and grid structures is shown in Fig. 3. In case of the first and second grids, the compression of cells was performed at inflow and outflow positions and at the storage tank walls. Meanwhile, the third grid consisted of all the same size cells. The size of one cell is $0.0619 \times 0.15 \mathrm{~m}$. The properties of the materials used in the numerical simulation are listed in Table 1 [15]. The calculation domain was subdivided into zones corresponding to the existing different physical materials in the storage tank.

TABLE I

\begin{tabular}{|c|c|c|c|}
\hline Property & Water $\left(20^{\circ} \mathrm{C}\right)$ & Steel $\left(27^{\circ}\right)$ & $\begin{array}{c}\text { Fiberglass } \\
\left(27^{\circ} \mathrm{C}\right)\end{array}$ \\
\hline Density, $\mathrm{kg} / \mathrm{m}^{3}$ & 998.23 & 7800.00 & 48.00 \\
\hline Viscosity, $\mathrm{m}^{2} / \mathrm{s}$ & $1.006 \cdot 10^{-6}$ & - & - \\
\hline $\begin{array}{l}\text { Specific heat capacity, } \\
\mathrm{J} /(\mathrm{kg} \cdot \mathrm{K})\end{array}$ & 4181.0 & 473.0 & 1100.0 \\
\hline $\begin{array}{l}\text { Thermal conductivity, } \\
\mathrm{W} /(\mathrm{m} \cdot \mathrm{K})\end{array}$ & 0.597 & 43.0 & 0.038 \\
\hline $\begin{array}{l}\text { Thermal expansion coeff., } \\
1 / \mathrm{K}\end{array}$ & $1.18 \cdot 10^{-4}$ & $0.37 \cdot 10^{-5}$ & $0.58 \cdot 10^{-5}$ \\
\hline Compressibility, $\mathrm{m}^{2} / \mathrm{N}$ & - & $0.5 \cdot 10^{-11}$ & $0.145 \cdot 10^{-10}$ \\
\hline Prandtl Number & 7.033 & - & - \\
\hline
\end{tabular}

PROPERTIES OF MATERIALS USED IN NUMERICAL SIMULATION
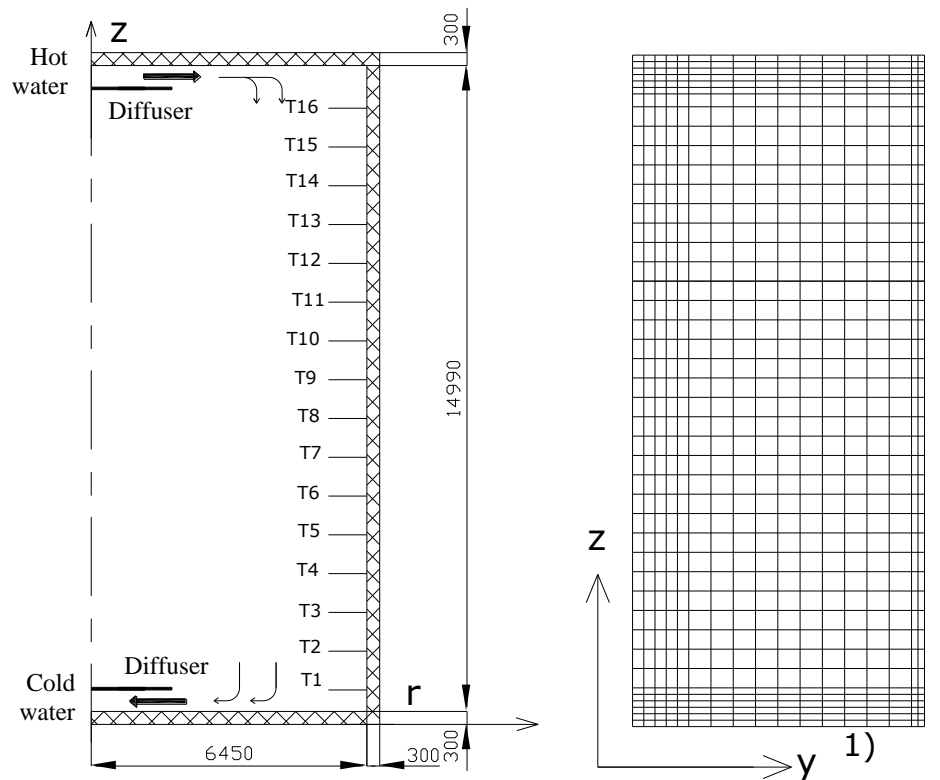

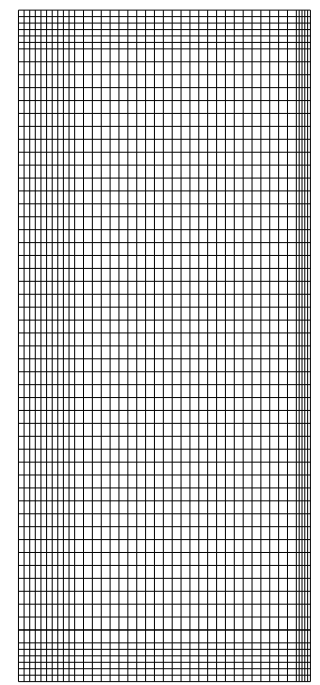

2)

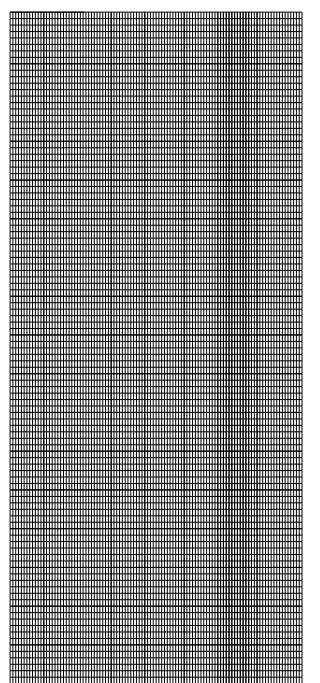

3)

Fig. 3. Simulated domain of the storage tank (on the left) and grids of numerical investigation: 1) $17 \times 43 ; 2$ ) $40 \times 58 ; 3$ ) $104 \times 104$ (on the right). 
It should be noted that using PHOENICS to simulate charging and discharging processes in the storage tank, it is necessary to differently describe the water density in the model. In the charging process, when using the $40 \times 58$ grid, the density was described in the following way:

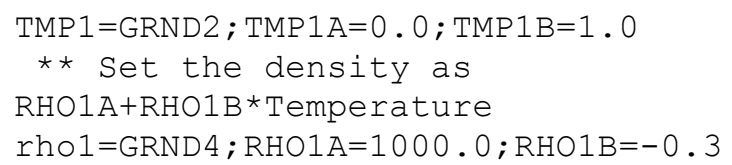

In the present case, the gravitational forces were the following expression:

PATCH (BUOYANCY, PHASEM, 1, 1, 1, 40, 1, 58, 1, 10)

COVAL (BUOYANCY, U1, FIXFLU, GRND2)

COVAL (BUOYANCY, V1, FIXFLU, GRND2)

COVAL (BUOYANCY, W1, FIXFLU, GRND2)

$\mathrm{BUOYA}=0.000000 \mathrm{E}+00 ; \mathrm{BUOYB}=0.000000 \mathrm{E}+00$

$\mathrm{BUOYC}=-9.810000 \mathrm{E}+00 ; \mathrm{BUOYD}=1.189000 \mathrm{E}+00$

$\mathrm{BUOYE}=2.000000 \mathrm{E}+01$

During the simulation of discharging processes, the density was not estimated as a function of temperature and the assumption of Boussinesq was applied:

PATCH (BUOYANCY, PHASEM, 1, 1, 1, 40, 1, 58, 1, 10)
COVAL (BUOYANCY, U1, FIXFLU, GRND3)
COVAL (BUOYANCY, V1, FIXFLU, GRND3)
COVAL (BUOYANCY, W1, FIXFLU, GRND3)

$\mathrm{BUOYA}=0.000000 \mathrm{E}+00 ; \mathrm{BUOYB}=0.000000 \mathrm{E}+00$ $\mathrm{BUOYC}=-9.810000 \mathrm{E}+00 ; \mathrm{BUOYE}=2.000000 \mathrm{E}+01$

where: GRND2 - selects a multiplier equal to (density BUOYD)/density; GRND3 - selects a multiplier equal to BUOYE + BUOYD*temperature; BUOYA - is used to carry the gravitational acceleration in the $x$-direction; BUOYB - is used to carry the gravitational acceleration in the $y$-direction; BUOYC - is used to carry the gravitational acceleration in the $z$-direction; BUOYD - is used in the calculation of buoyancy forces to carry reference density for the GRND2 option; BUOYE - is used to carry the reference temperature in GRND3 option for calculation of buoyancy forces [15].

Such description of the gravitational forces made it possible to simulate temperature distribution in the tank.

\section{MODEL VALIDATION}

The numerical PHOENICS model has been validated by comparing its results against some experimental and numerical results from the literature review. The work of Zachar et al. (2003) [16], in which different plate sizes were analyzed to obtain thermal stratification in a small size hot water tank, was used. It was applied to our model to the geometry used in this study and obtained the results for vertical thermal stratification after the discharging process under the same operating conditions as in this paper.

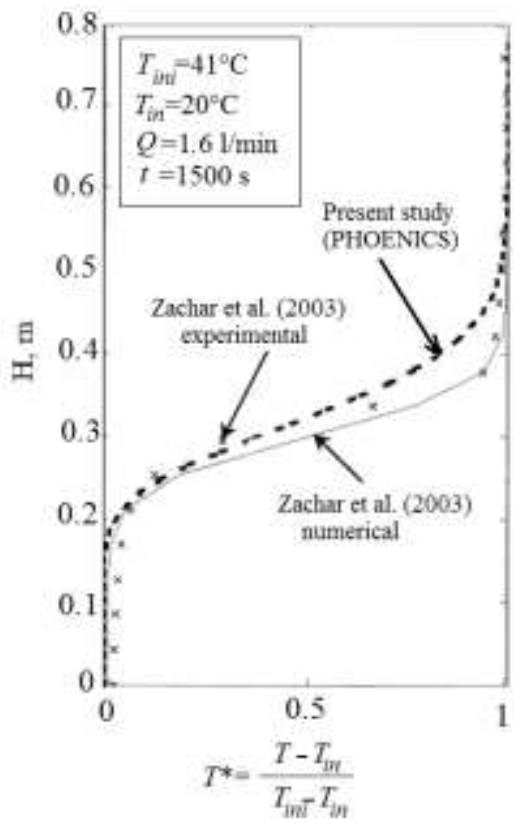

Fig. 4. Vertical temperature distribution comparing the results of this work with Zachar et al. (2003) results.

where: $T$ - temperature of the water inside the tank, $T_{i n}-$ inlet temperature, $T_{i n i}$ - initial temperature of the water.

The comparison of the results of the created numerical model and the numerical and experimental results of Zachar et al. (2003) showed good agreement as shown in Fig. 4. This shows that our model can be applied for storage tanks of various size and shape.

\section{V.RESULTS AND DISCUSSION}

The numerical simulation of temperature stratification in the storage tank used in the CHP plant is done using the main parameters of charging and discharging processes of the Hvide Sande storage tank. These parameters are showed in Table 2, where values of flow rate and ambient temperature for an appropriate time period are calculated as the average values. All analyzed processes last from $15 \mathrm{~min}$ to $6 \mathrm{~h}$. A different number of time steps (from 5 to 200) was tested in the numerical simulation. The research chose to use 50 time steps for further analysis. The chosen number of time steps allowed to quickly and accurately simulate the processes inside the heat storage tank. The charging and discharging process with the biggest flow rate (ID 2443 and ID 231) was chosen in order to test PHOENICS models which use different grids.

Knowing the initial temperature distribution of the Hvide Sande storage tank, the latter temperature values are calculated using different grids. In the first, the charging process of $15 \mathrm{~min}$ is simulated. The comparison of calculated thermal stratification and measured thermal stratification after $15 \mathrm{~min}$ and $6 \mathrm{~h}$ is presented in Fig. 5. The discharging process was simulated similarly and is presented in Fig. 6. As can be seen from the processes which are short $(15 \mathrm{~min})$, the simulation results of all three discretization grids meet the actual temperature values of sensors installation places very well. 
TABLE II

SPECIFICATION OF CHARGING AND DISCHARGING PROCESSES

\begin{tabular}{|c|c|c|c|c|c|c|c|}
\hline \multirow{2}{*}{ ID } & \multirow{2}{*}{ Parameter } & \multicolumn{6}{|c|}{ Time } \\
\hline & & $15 \mathrm{~min}$ & $30 \mathrm{~min}$ & $1 \mathrm{~h}$ & $2 \mathrm{~h}$ & $4 \mathrm{~h}$ & $6 \mathrm{~h}$ \\
\hline \multicolumn{8}{|c|}{ Charging processes } \\
\hline \multirow{2}{*}{176} & Ambient temperature and measurement error, ${ }^{\circ} \mathrm{C}$ & $6.7 \pm 0.3$ & $6.7 \pm 0.3$ & $6.7 \pm 0.3$ & $6.8 \pm 0.3$ & $7.2 \pm 0.3$ & $7.6 \pm 0.3$ \\
\hline & Flow rate and measurement error, $\mathrm{m}^{3} / \mathrm{h}$ & $40.2 \pm 0.9$ & $38.9 \pm 0.9$ & $38.1 \pm 0.9$ & $43.0 \pm 1.0$ & $47.3 \pm 1.1$ & $51.5 \pm 1.2$ \\
\hline \multirow{2}{*}{742} & Ambient temperature and measurement error, ${ }^{\circ} \mathrm{C}$ & $8.3 \pm 0.3$ & $8.3 \pm 0.3$ & $8.3 \pm 0.3$ & $8.3 \pm 0.3$ & $8.1 \pm 0.3$ & $7.7 \pm 0.3$ \\
\hline & Flow rate and measurement error, $\mathrm{m}^{3} / \mathrm{h}$ & $63.4 \pm 1.4$ & $63.1 \pm 1.4$ & $61.5 \pm 1.4$ & $67.6 \pm 1.5$ & $66.5 \pm 1.5$ & $65.3 \pm 1.4$ \\
\hline \multirow{2}{*}{2443} & Ambient temperature and measurement error, ${ }^{\circ} \mathrm{C}$ & $10.9 \pm 0.4$ & $11.0 \pm 0.4$ & $11.3 \pm 0.4$ & $11.5 \pm 0.4$ & $11.6 \pm 0.4$ & $11.6 \pm 0.4$ \\
\hline & Flow rate and measurement error, $\mathrm{m}^{3} / \mathrm{h}$ & $82.8 \pm 2.1$ & $82.5 \pm 2.1$ & $81.1 \pm 2.1$ & $82.1 \pm 2.1$ & $83.4 \pm 2.1$ & $83.6 \pm 2.1$ \\
\hline \multicolumn{8}{|c|}{ Discharging processes } \\
\hline \multirow{2}{*}{231} & Ambient temperature and measurement error, ${ }^{\circ} \mathrm{C}$ & $5.9 \pm 0.3$ & $5.8 \pm 0.3$ & $5.8 \pm 0.3$ & $5.7 \pm 0.3$ & $5.8 \pm 0.3$ & $5.9 \pm 0.3$ \\
\hline & Flow rate and measurement error, $\mathrm{m}^{3} / \mathrm{h}$ & $93.2 \pm 2.3$ & $93.4 \pm 2.3$ & $93.2 \pm 2.3$ & $93.9 \pm 2.3$ & $93.6 \pm 2.3$ & $95.0 \pm 2.4$ \\
\hline \multirow{2}{*}{1708} & Ambient temperature and measurement error, ${ }^{\circ} \mathrm{C}$ & $12.5 \pm 0.4$ & $12.4 \pm 0.4$ & $12.4 \pm 0.4$ & $12.1 \pm 0.4$ & $11.4 \pm 0.4$ & $10.4 \pm 0.4$ \\
\hline & Flow rate and measurement error, $\mathrm{m}^{3} / \mathrm{h}$ & $72.0 \pm 1.8$ & $72.4 \pm 1.9$ & $71.8 \pm 1.8$ & $72.9 \pm 1.9$ & $74.0 \pm 1.9$ & $74.1 \pm 1.9$ \\
\hline \multirow{2}{*}{3748} & Ambient temperature and measurement error, ${ }^{\circ} \mathrm{C}$ & $17.3 \pm 0.4$ & $17.3 \pm 0.4$ & $17.1 \pm 0.4$ & $16.7 \pm 0.4$ & $16.0 \pm 0.4$ & $15.6 \pm 0.4$ \\
\hline & Flow rate and measurement error, $\mathrm{m}^{3} / \mathrm{h}$ & $44.8 \pm 1.3$ & $44.8 \pm 1.3$ & $44.5 \pm 1.3$ & $44.4 \pm 1.3$ & $44.4 \pm 1.3$ & $44.9 \pm 1.3$ \\
\hline
\end{tabular}

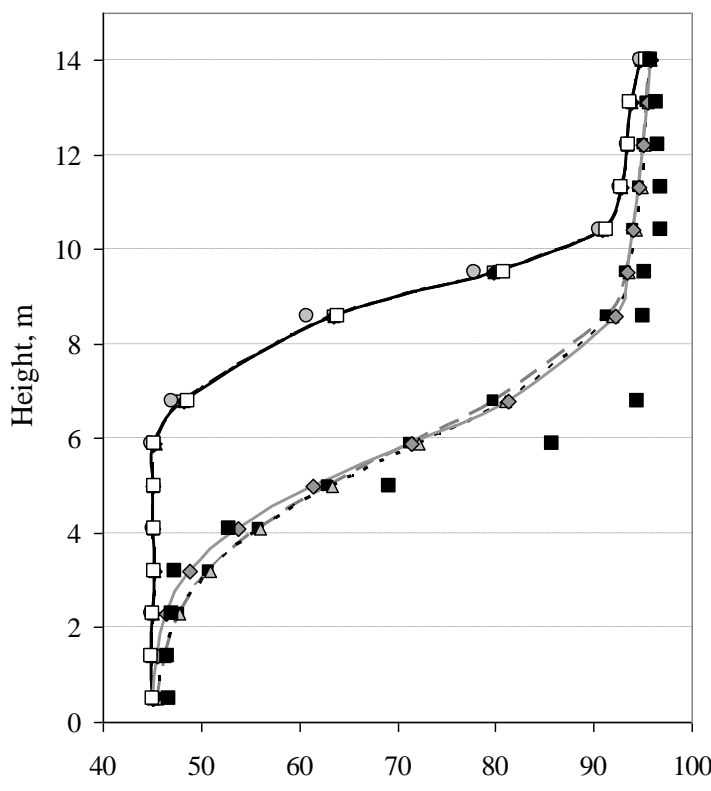

Temperature, ${ }^{\circ} \mathrm{C}$

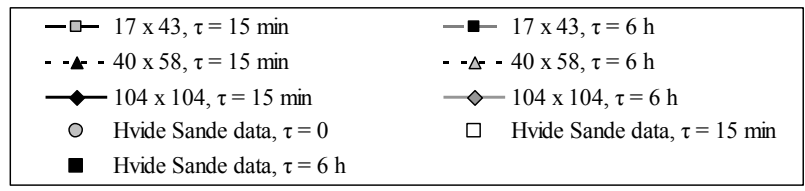

Fig. 5. Temperature distribution of charging process using different grids.

When the charging or discharging process lasts $15 \mathrm{~min}$, the obtained temperature distribution curves of models, which use different grids, coincide. When the period of the simulated process is longer, the temperature discrepancies are bigger, especially in the intermediate temperature zone. The biggest discrepancies of temperature were obtained at the $8^{\text {th }}$ sensor.

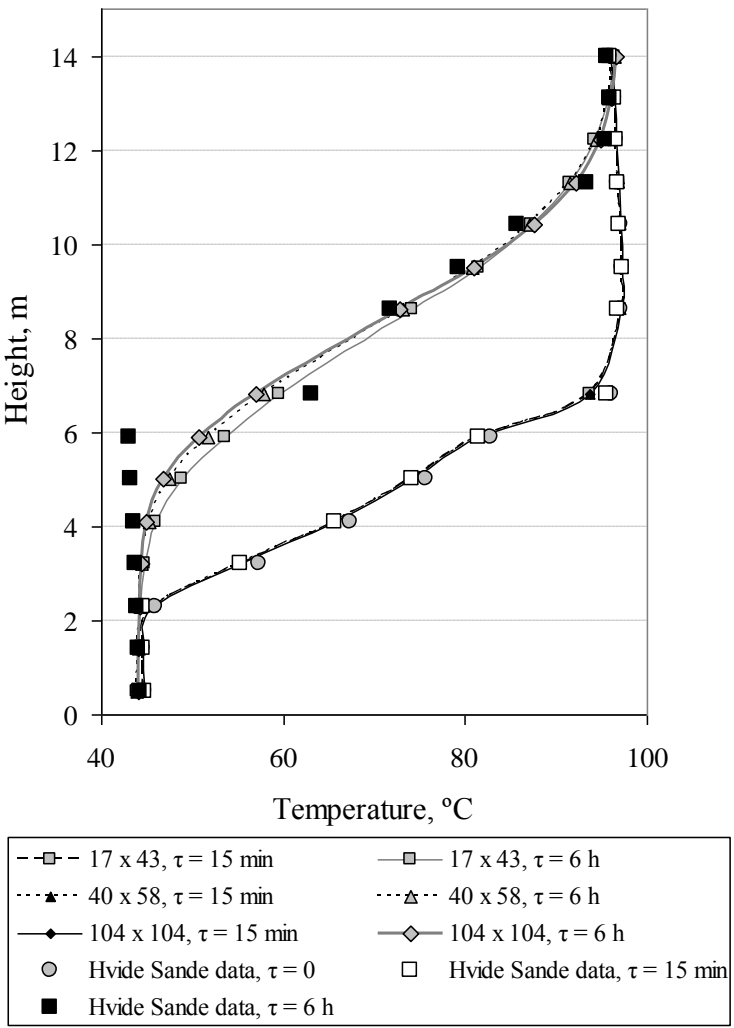

Fig. 6. Temperature distribution of discharging process using different grids.

This situation can be explained by the fact that the temperature value of the $9^{\text {th }}$ sensor is not available during the simulation and the model calculates the corresponding temperatures of the layers as the average temperatures between the adjacent layers. Moreover, this point falls in the intermediate temperature zone, where the temperature changes significantly. 


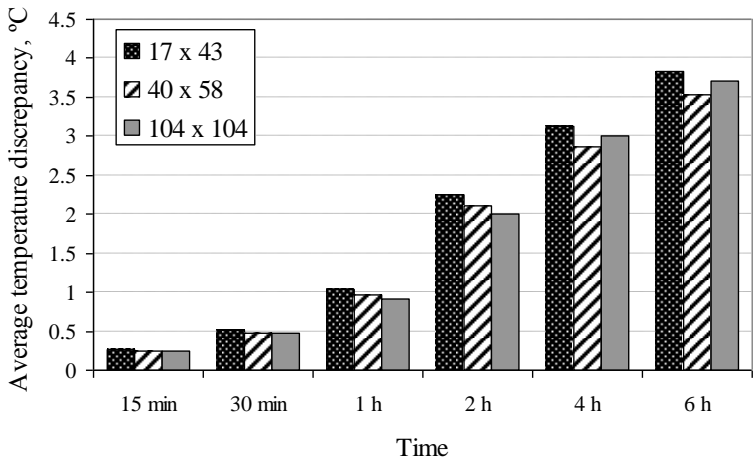

Fig. 7. Average temperature discrepancy of charging process using different grids.

The data of the $9^{\text {th }}$ sensor should be obtained and the space grid of this site should be denser in order to simulate the more accurate thermal stratification at the $8^{\text {th }}$ sensor field of the storage tank of the Hvide Sande CHP plant.

The assessment of the model's accuracy is conducted using an average discrepancy of temperature. Average temperature discrepancies using different grids are presented in Fig. 7 and Fig. 8. It can be seen that the minimum discrepancies of temperature are obtained when the simulation processes are shortest. The maximum discrepancy is reached when the process lasts $6 \mathrm{~h}$.

The most accurate results were obtained simulating the long-term charging, using a grid of $40 \times 58$, the calculated average temperature discrepancy for $4 \mathrm{~h}$ charging process was $2.86{ }^{\circ} \mathrm{C}$ and $6 \mathrm{~h}-3.53{ }^{\circ} \mathrm{C}$. The least accurate results were obtained using the largest grid $-17 \times 43$. When the $4 \mathrm{~h}$ and $6 \mathrm{~h}$ charging process were simulated, it was found that the average temperature discrepancy is $3.14^{\circ} \mathrm{C}$ and $3.84^{\circ} \mathrm{C}$.

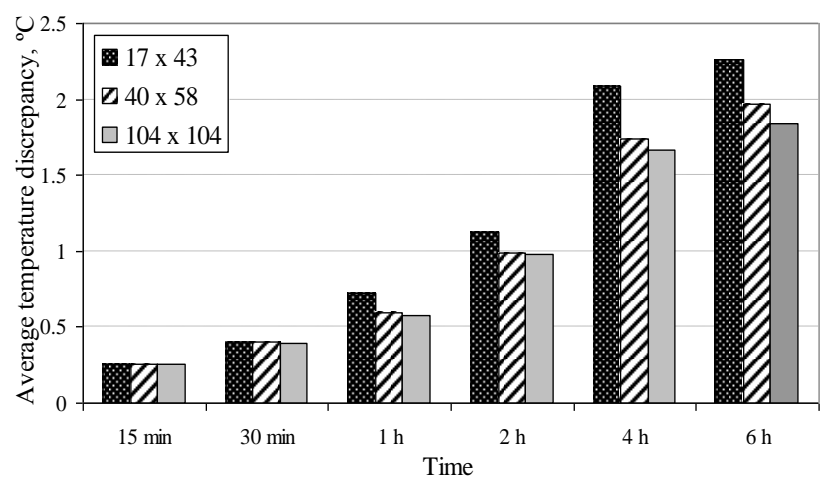

Fig. 8. Average temperature discrepancy of discharging process using different grids.

In all discharging process cases, the most accurate results were obtained by using a $104 \times 104$ cells grid, the least accurate results with the largest grid of $17 \times 43$ cells.

It should be noted that the density of the space grid has the effect on the length of the calculation time. Considering the accuracy of the tested grids and the computing time, the $40 \times$ 58 grid was chosen for further calculations.

\section{A. Three-dimensional problem (3D)}

To verify the possibility to transform a $2 \mathrm{D}$ model to a $3 \mathrm{D}$ model, the space around the central axis was divided into ten parts. A grid of $40 \times 58 \times 10$ cells (total 23200 ) was made for the calculation.

The temperature distribution and velocity field after $4 \mathrm{~h}$ of discharging (ID 231) was computed using 2D and 3D models and is presented in Fig. 9.
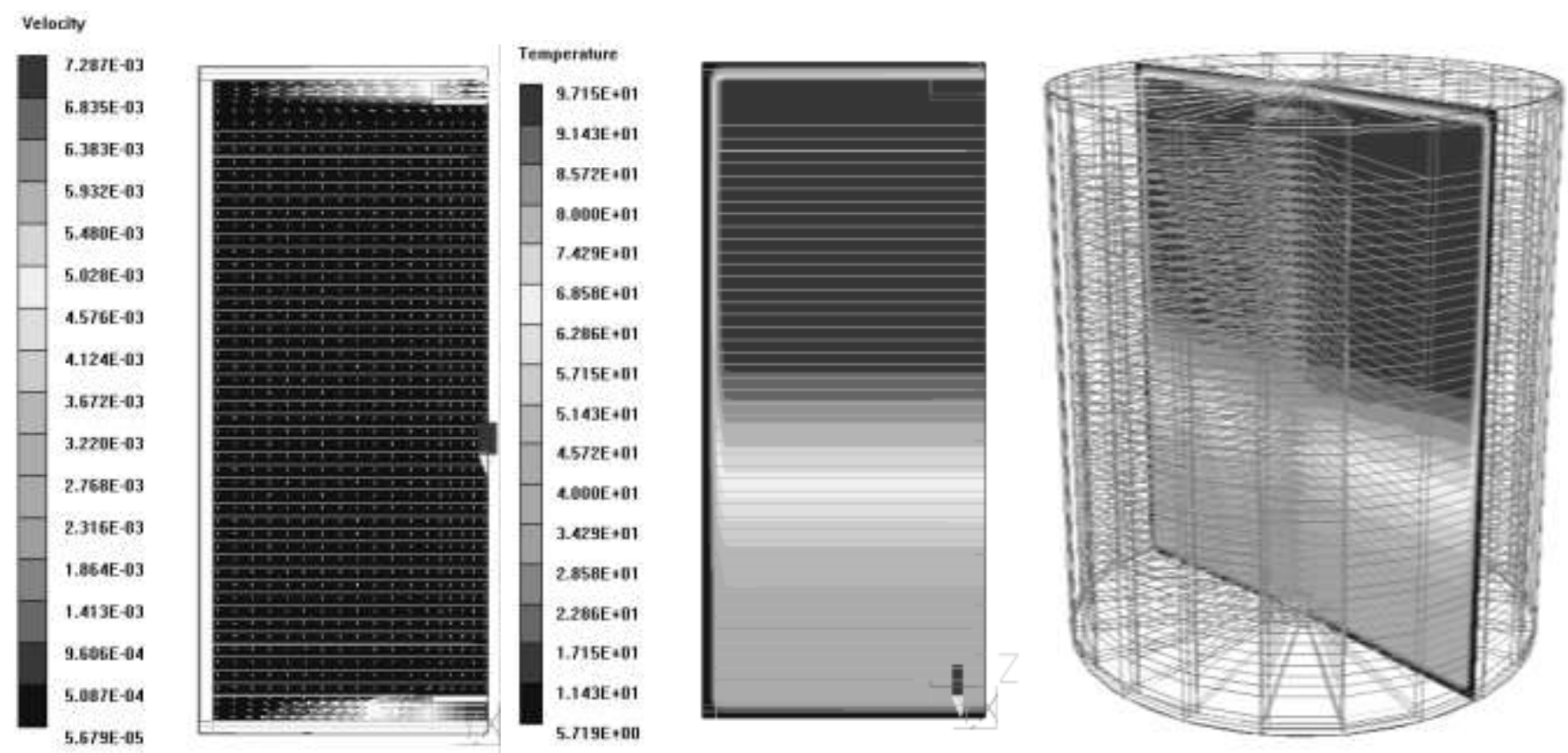

Fig. 9. Temperature distribution and velocity field after $4 \mathrm{~h}$ of discharging in 2D and 3D models. 


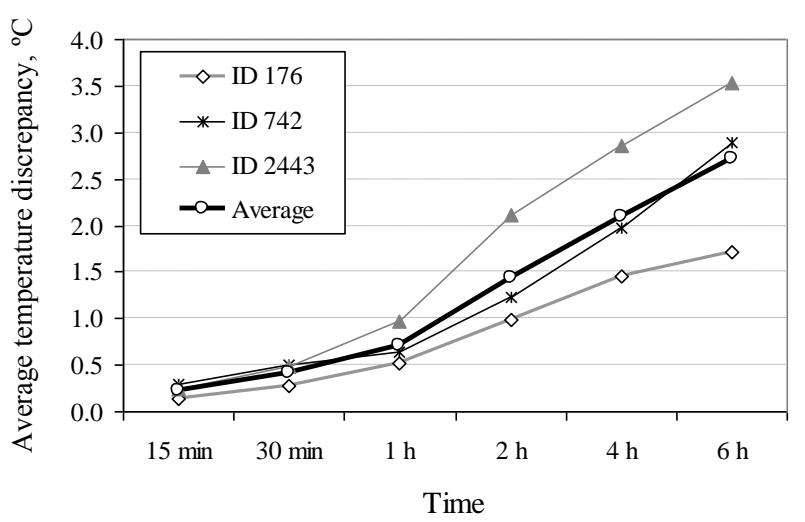

Fig. 10. Average temperature discrepancy of charging processes.

Temperatures around the symmetry axis ( $\mathrm{z}$ ) remain the same in the 3D case and the temperature difference is not apparent visually. Considering PHOENICS results file (results), minor temperature discrepancies were obtained between results of the $2 \mathrm{D}$ and $3 \mathrm{D}$ model in the corresponding height.

The maximum flow velocities are at the inlet and outlet of the tank. Meanwhile, the vertical velocity varies from $10^{-}$ ${ }^{4} \mathrm{~m} / \mathrm{s}$ to $10^{-5} \mathrm{~m} / \mathrm{s}$ in a major part of the tank.

It was determined that there is no significant difference between the results of the 2D and 3D models because similar average relative temperature discrepancies are obtained, if the inlet and outlet openings or diffusers are arranged symmetrically around the vertical axis. However, the computing time of the $2 \mathrm{D}$ model is 5 times shorter than the 3D model.

\section{B. Modelling of processes with various flow rates}

All charging and discharging processes were simulated using a $40 \times 58$ space grid in cylindrical polar coordinates. The time of simulation was divided into 50 time steps, and 10 iterations were selected for counting and the value of relaxation coefficient was $10^{9}$.

The average temperature discrepancies calculated for simulated charging and discharging processes (Table 2) are shown in Fig. 10 and Fig. 11. The simulations of charging processes showed that when the inlet flow rate increases, the accuracy of the results decrease proportionally. The estimated average temperature discrepancy during the three charging processes cases varied in the range from $0.23{ }^{\circ} \mathrm{C}$ to $2.71{ }^{\circ} \mathrm{C}$. Meanwhile, in simulations of discharging processes cases, the inlet cold water flow rate size did not significantly affect the model accuracy. The largest discrepancies were obtained for the intermediate temperature zone. The average temperature discrepancies for three simulated processes ranged from $0.28^{\circ} \mathrm{C}$ to $2.08^{\circ} \mathrm{C}$.

\section{Performance of thermal stratification}

Several dimensionless numbers can be used to characterize thermal stratification in water storage tanks [4]. Stratification number is selected in this work.

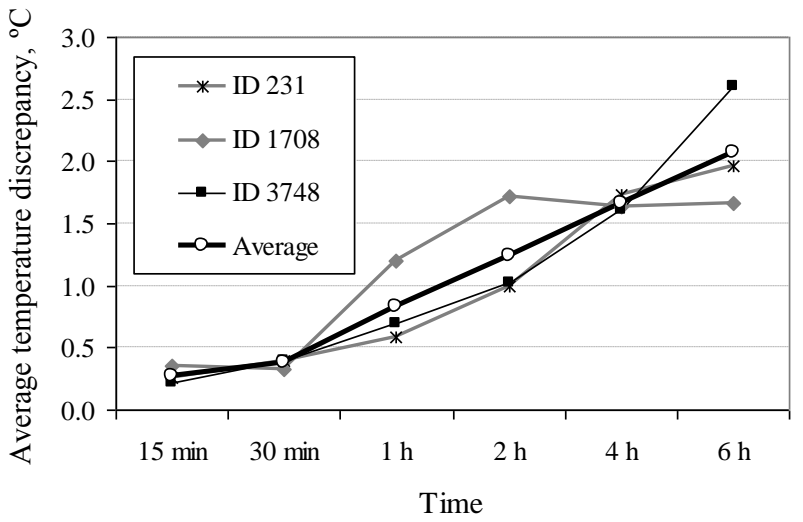

Fig. 11. Average temperature discrepancy of discharging processes.

For the dynamic mode of operation, the stratification number is defined as the ratio of the mean of the temperature gradients at any time to the maximum mean temperature gradient for the discharging/charging process, according to this equation $[8,17]$ :

$$
\begin{gathered}
\operatorname{Str}(\tau)=\frac{\overline{(\partial T / \partial z)_{\tau}}}{(\partial T / \partial z)_{\max }}, \\
\overline{(\partial T / \partial z)_{\tau}}=\frac{1}{J-1}\left[\sum_{j=1}^{J-1}\left(\frac{T_{j+1}-T_{j}}{\Delta z}\right)\right], \\
(\partial T / \partial z)_{\max }=\frac{T_{\max }-T_{i n}}{(J-1) \Delta z},
\end{gathered}
$$

where: $J$ - number of water layers, $j$ - water layer, $\Delta z-$ distance between temperature sensors, $T$ - temperature, max - maximum, in - inlet.

The mean maximum temperature gradient is obtained considering that the maximum temperature difference during the charging or discharging process is concentrated in only one of the water layers considered in this analysis; then the gradient in the remaining layers is zero [17].

The assessment of thermal stratification was based on the real Hvide Sande CHP plant heat storage tank data collected from 2008-04-02 to 2008-06-18. The data were registered in a 15 minute interval. The flow rate of inlet/outlet water ranged from 0 to $150 \mathrm{~m}^{3} / \mathrm{h}$ and the average flow rate was $61.9 \mathrm{~m}^{3} / \mathrm{h}$ during the reporting period.

It is found that the inlet /outlet water flow rate affects the degree of stratification. It was also determined that, when the intermediate temperature zone in the Hvide Sande CHP plant storage tank increases, the Str value decreases linearly. This is illustrated in Fig. 12. 


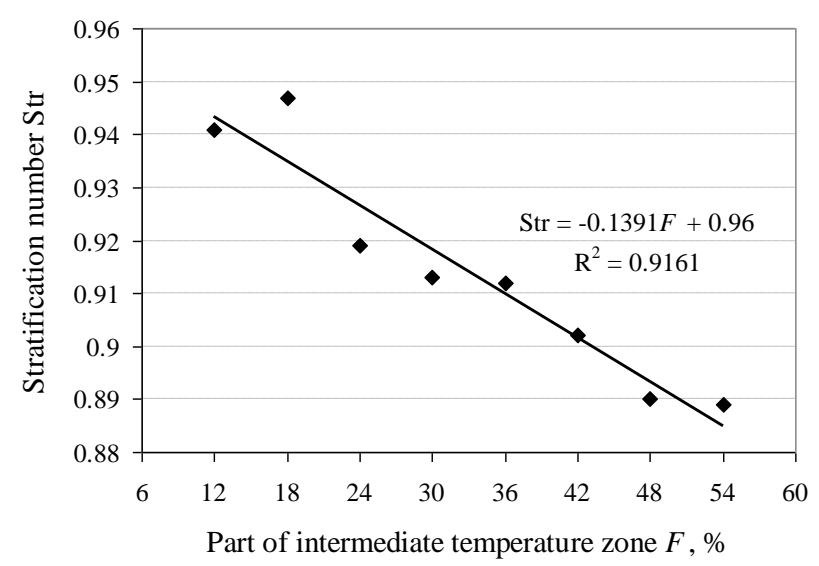

Fig. 12. Dependency of Str on intermediate temperature zone.

The average stratification number 0.913 was determined during the analysis. The high value of the stratification number shows a good fulfilment of design and operating conditions of the storage tank. It was estimated when the inlet/outlet flow rate was $0-100 \mathrm{~m}^{3} / \mathrm{h}, S t r=0.914$ and when there was a higher flow rate, i. e. $100-150 \mathrm{~m}^{3} / \mathrm{h}$, Str $=0.909$. Most of the time (42\%) the flow rate varied in the range from 40 to $60 \mathrm{~m}^{3} / \mathrm{h}$, and the average stratification number was 0.915 .

\section{CONCLUSIONS}

Different ways may be used to determine the thermal stratification that is formed in the storage tank operating in the real cogeneration plant. The analysis has shown that using the PHOENICS software can be accurate $\left(\sim 3.5^{\circ} \mathrm{C}\right.$ average temperature discrepancy) sufficiently to allow investigation of the evolution of the temperature distribution ongoing in such storage tanks. The numerical simulation provides information not only on thermal stratification but also about the field of velocities.

The comparison of two-dimensional and three-dimensional numerical models revealed that, if the flow inlet and outlet holes and the geometry of the storage tank are symmetrical about the vertical mid-axis, there is no significant difference between the accuracy of the results of these models. However, the three-dimensional problem solution takes 5 times longer than the two-dimensional, when the computational area increases 10 times.

Creating a numeric model by PHOENICS software, it was determined that different gravitational forces description should be used when describing charging and discharging processes. The simulation of different flow rates of charging and discharging processes showed that the charging process simulation accuracy is affected by the flow rate, while the discharging process simulation is not significantly affected by the incoming cold water flow rate.

During the Hvide Sande CHP plant heat storage tank data analysis, it was determined that when increasing the proportion of the intermediate temperature zone of the tank, the stratification number decreases linearly.

\section{REFERENCES}

1. Haeseldockx, D., Peeters, L., Helsen, L., et al. The impact of thermal storage on the operational behaviour of residential CHP facilities and the overall $\mathrm{CO}_{2}$ emissions. Renewable and Sustainable Energy Reviews, 2007, vol. 11, p. 1227-1243.

2. Fragaki, A., Andersen, A. N., Tokde, D. Exploration of economical sizing of gas engine and thermal store for combined heat and power plants in the UK. Energy, 2008, vol. 33, p. 1659-1670.

3. Streckienė, G., Martinaitis, V., Andersen, A. N., Katz, J. Feasibility of CHP-plants with thermal stores in the German spot market. Applied Energy, 2009, vol. 86, p. 2308-2316.

4. Castell, A., Medrano, M., Solé, C., Cabeza, L. F. Dimensionless numbers used to characterize stratification in water tanks for discharging at low flow rates. Renewable Energy, 2010, vol. 35, p. 2192-2199.

5. Dincer, I., Rosen, M. A. Thermal energy storage: systems and application. Wiley, 2002. $579 \mathrm{p}$.

6. Ong, K. S. A finite-difference method to evaluate the thermal performance of a solar water heater. Solar Energy, 1974, vol. 16, p. 137-147.

7. Butz, L. W., Beckman, A. W., Duffie, J. A. Simulation of a solar heating and cooling system. Solar Energy, 1974, vol. 16, p. 129-136.

8. Han, Y. M., Wang, R. Z., Dai, Y. J. Thermal stratification within the water tank. Renewable and Sustainable Energy Reviews, 2009, vol. 13, p. 1014-1026.

9. Garnier, C., Currie, J., Muneer, T. Integrated collector storage solar water heater: temperature stratification. Applied Energy, 2009, vol. 86, p. $1465-1469$

10. Jordan, U., Furbo, S. Thermal stratification in small solar domestics storage tanks caused by draw-offs. Solar Energy, 2005, vol. 78, p. 291-300

11. Spur, R., Fiala, D., Nevrala, D., Probert, D. Performance of modern domestic hot-water stores. Applied Energy, 2006, vol. 83, p. 893-910.

12. Hvide Sande District Heating [Online] [Accessed 14.07.2011]. Available:

http://www.emd.dk/desire/HvideSande/Hvide_Sande_UK.html

13. Streckiene, G., Martinaitis, V., Vaitiekunas, P. Simulation of thermal stratification in the heat storage for CHP plant. In: The $8^{\text {th }}$ International Conference of Environmental Engineering, Vilnius, Lithuania, May 19-20, 2011. Selected paper, p. 812-819.

14. Vaitiekūnas, P., Špakauskas, V. Šilumos ir masès pernašos procesu aplinkoje modeliavimo principai [Fundamentals of simulation of heat and mass transfer processes in environment]. Vilnius, Technika, 2003. $195 \mathrm{p}$.

15. PHOENICS [Online]. Index to the PHOENICS encyclopedia [Accessed 18.07.2011]. Available: http://www.cham.co.uk/phoenics/d polis/d enc/encindex.htm

16. Zachar, A., Farkas, I., Szlivka, F. Numerical analyses of the impact plates for thermal stratification inside a storage tank with upper and lowe inlet flows. Solar Energy, 2003, vol. 74, p. 287-302.

17. Fernández-Seara, J., Uhía, F. J., Sieres, J. Experimental analysis of a domestic electric hot water storage tank. Part II: dynamic mode of operation. Applied Thermal Engineering, 2007, vol. 27, p. 137-144.

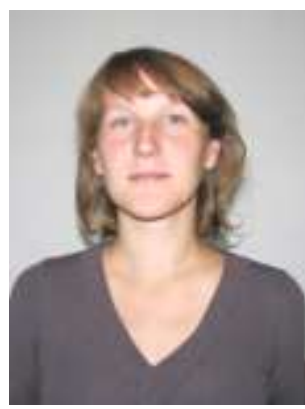

Giedre Streckiene, Dr., Vilnius Gediminas Technical University, Faculty of Environmental Engineering, Department of Building Energetics. Dr. Giedre Streckiene has been part of academic staff of Faculty of Environmental Engineering, Vilnius Gediminas Technical University since 2006. She received M. Sc. degree in energetics and power engineering (2006). PhD thesis "Research of heat storage tank operation modes in cogeneration plant" was defended in Vilnius Gediminas Technical University (2011). The main research area is cogeneration and thermal energy storage technologies. She has over 10 publications. Address: Sauletekio ave. 11, LT-10223, Vilnius, Lithuania Phone: +37052744718

E-mail: giedres@mailas.com 


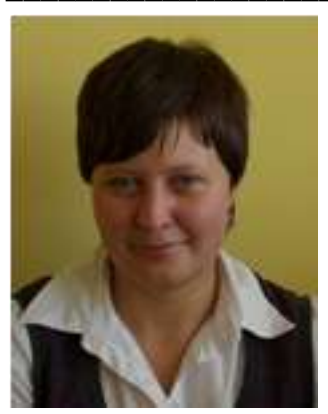

Violeta Miseviciute, M.Sc., assistant, Vilnius Gediminas Technical University, Department of Building Energetics. She has Energetics Master Diploma (2007). During the master studies (2006-2007) has been studied Sustainable energy planning program at Aalborg University in Denmark. The main research area is efficiency use of energy in building engineering systems. She is an assistant of department of Building Energetics and doing the $\mathrm{PhD}$ thesis "Evaluation of possibilities for processes integration in ventilation equipment" from 2007 till now.
She has participated in international project related to building refurbishment, as well as is author of 7 publications.

E-mail: violeta.miseviciute@vgtu.lt

Giedre Streckiene, Violeta Misevičiute. Koğenerācijas stacijas siltuma uzglabāšanas tvertnes darb̄̄bas režīmu izpēte, izmantojot skaitlisko modelēšanu. Siltuma akumulācijas rezervuāra uzstādīšana l̦auj uzlabot koǵenerācijas stacijas darbību un padara sistēmu elastīgu. Parasti šāda veida rezervuāri glabā termiskās stratifikācijas siltumu, tie ḷauj atdalīt karstā un aukstā ūdens slāṇus vienā rezervuārā. Stratifikācijas rezervuārā karstais ūdens (ar mazāku blīvumu) ceḷas uz augšu, bet blīvākais aukstais ūdens nolaižas uz leju. Karstais un aukstais ūdens rezervuārā sadalās divos slāņos, starp kuriem rodas vēl viens slānis ar pārejas temperatūru. Darbā tiek apskatīta koǵenerācijas stacijā uzstādītā akumulācijas rezervuāra darbības režīmu skaitliskā modelēšana. Skaitliskā modelēšana tika veikta izmantojot programmu PHOENIC šķidruma dinamikas aprēķiniem. Tika izmantoti 2D un 3D nestacionārie modeḷi. 2D un 3D modeḷu salīdzinājums paradīja, ka, ja ieejas uz izejas plūsma un akumulācijas rezervuāra ğeometrija ir simetriska atbilstoši augšějās ass vidum, tad nav būtiskas atšḳkirības precizitātē starp diviem modeliem. Problēmas risinājums ar 3D modeli aizṇem 5 reizes ilgāku laika periodu nekā ar 2D modeli, palielinot aprēkina apgabalu 10 reizes.

Darbā tika izmēǵināti trīs aprēķina veidi. Modęa rezultātu pārbaude tika veikta, salīdzinot koǵenerācijas stacijas siltuma akumulācijas rezervuāra faktiskos datus Hvide Sande ar modelēšanas rezultātiem. Modelējot uzlādēšanas un izlādēšanas procesus ar dažādam plūsmām, tika atklāts, ka plūsmas uzlādēšanas procesu modelēšanas precizitāte ir atkarīga no plūsmas ātruma, bet izlādēšanas procesa modelěšanas precizitāte nelielā mērā ir atkarīga no aukstā ūdens ieejas plūsmas. Koğenerācijas stacijas Hvide Sande datu analīze paradīja, ka, palielinot slāni ar pārejas temperatūru, stratifikācijas skaitlis samazinās ar lineāru sakarību. 